\title{
Effects of Environmental Temperature and Precipitation Pattern on Growth Stages of Mangifera indica cv. Harumanis Mango
}

\author{
Shaidatul Azdawiyah Abdul Talib ${ }^{1}$, Muhamad Hafiz Muhamad Hassan ${ }^{1}$, Mohd Aziz Rashid ${ }^{1}$, \\ Zul Helmey Mohd Sabdin ${ }^{1}$, Muhammad Zamir Abdul Rashid ${ }^{1}$, Wan Mahfuzah Wan Ibrahim ${ }^{1}$, \\ Mohammad Hariz Abdul Rahman ${ }^{1}$, Mohd Ghazali Rusli ${ }^{1}$, Syarol Nizam Abu Bakar ${ }^{1}$ \\ \& Mohd Alif Omar Mustaffa ${ }^{1}$ \\ ${ }^{1}$ Malaysian Agricultural Research and Development Institute (MARDI), Selangor, Malaysia \\ Correspondence: Shaidatul Azdawiyah Abdul Talib, Malaysian Agricultural Research and Development Institute \\ (MARDI), MARDI Headquarters, Persiaran MARDI-UPM, 43400 Serdang, Selangor, Malaysia. E-mail: \\ azdawiyah@mardi.gov.my
}

Received: September 1, 2020

Accepted: October 28, 2020

Online Published: November 15, 2020

doi:10.5539/jas.v12n12p26

URL: https://doi.org/10.5539/jas.v12n12p26

\begin{abstract}
Mangifera indica $\mathrm{cv}$. Harumanis is one of the most commercially grown mango cultivar in Malaysia due to market demand and price. However, the fruit supply never meets the demand as Harumanis is highly sensitive towards the climate and only grows in Perlis and part of Kedah. Crop productivity and development are mainly related to climatic variables where temperature and precipitation are the most importance. Temperature and precipitation distribution pattern affect flowering, fruit set, fruit growth and also fruit development. This study evaluates the relationship between temperature and precipittaion distribution pattern towards development of Harumanis growth stages including flowering and fruit development aspects in Zone 1 (area with a clear dry season up to three or four months) and Zone 2 (area with a clear dry season between one to two months). Thermal calendar based on daily and accumulated growing degree days (GDD) used to predict growth stages. Results indicate that Harumanis need a hot and dry environment (high temperature with less precipitation) during reproductive stage. However, there is no significant difference between Zone 1 and Zone 2 on the GDD required during every growth stages. On yield and fruit quality aspects, Zone 1 produced higher yield and better quality than Zone 2 due to the environmental factor even though there is no significant difference. Future study needs to be done as this information together with projection of future climate change scenarios are crucial in developing Decision Support Tool (DST) to guide the farmers in planning their crop management practices for the upcoming season.
\end{abstract}

Keywords: climatic variables, crop production, yield and fruit quality

\section{Introduction}

Mango (Mangifera indica L., Family Anacardiaceae) is among the most economically and culturally important tropical fruits, especially in Asia. It was originally found in the foothills of the Himalayas in North Eastern India, Burma, and Bangladesh besides being a popular evergreen fruit tree natural to South Eastern Asia (Litz, 2009). Mango is one of the ancient and high-quality tropical fruits of the world and is appropriately chosen as "king of fruits" in the tropical world (Kanzaria et al., 2015; Singh et al., 2011). Mango popular for its excellent taste, attractive aroma and high nutritional value, thus gradually gaining global market (Kanzaria et al., 2015; Farheen et al., 2019). Harumanis cultivar is one of the most commercially grown mango in Malaysia for local trade and export. High demand of Harumanis is due to its unique sweetness and aroma compared to another cultivar. However, due to sensitivity towards environment and climate, Harumanis can only be found in Perlis and some part of Kedah. Harumanis is highly sensitive to the climate, as it requires a significant dry weather period to initiate flowering. Moreover, Harumanis productive phase can be significantly affected by changes in weather. Harumanis is available only for a limited period, which is from the middle of April until the middle of June annually, making the cultivar the most sought-after in the country (Farook et al., 2012). Thus, the fruit supply can never meet the market demand.

Global warming and climate change have reached the alarming levels due to increase of anthropogenic GHG emissions into the atmosphere. This issue had been a global concern for the past 20 years as human activities are 
the main contributor of climate change (Shaidatul et al., 2015; Sarker, 2012). The world is experiencing an unprecedented rise in surface temperature (Shaidatul et al., 2015; Adhya et al., 2000). There is an increase in global surface temperature by $0.74 \pm 0.18{ }^{\circ} \mathrm{C}$ between the beginning and the end of the $20^{\text {th }}$ century, and it is projected to increase by 1.1 to $6.4{ }^{\circ} \mathrm{C}$ in the $21^{\text {st }}$ century (Shaidatul et al., 2015; Baicich, 2013). In Malaysia, the average annual air temperature for the country may increase by 0.5 to $1.0^{\circ} \mathrm{C}$ during the period of 2030 , and it may further increase up to 0.9 to $1.6^{\circ} \mathrm{C}$ during the period of 2050 (MESTECC, 2018).

Intergovernmental Panel on Climate Change (IPCC) had published a special report on emission scenarios, where IPCC classified the emission scenarios into four groups, which are A1, B1, A2 and B2 as the possible future climate change. The set of scenarios consists of six scenario groups drawn from the four families; one group each in A2, B1, B2, and three groups within the A1 family, which are A1FI (fossil fuel intensive), A1B (balanced), and A1T (predominantly non-fossil fuel). General circulation models (GCM) projected all these scenarios by considering all together the physical of atmosphere, ocean, cryosphere and land surfaces (Randall et al., 2007). In Malaysia, PRECIS is currently being used to project SRES A1B emission climate scenario for peninsular Malaysia, Sabah and Sarawak. PRECIS is one of the RCM developed by Met Office Hadley Centre where the model was configured to cover horizontal grid resolution of $0.22^{\circ} \times 0.22^{\circ}$ and 19 levels of hybrid vertical coordinate from ground up to $0.5 \mathrm{hpa}$ (Meng et al., 2013).

As for Peninsular and East of Malaysia, the modelling is focused on $95^{\circ} \mathrm{E}$ to $123^{\circ} \mathrm{E}$ and $7.5^{\circ} \mathrm{S}$ to $14^{\circ} \mathrm{N}$ respectively. PRECIS downscales with coarser spatial resolution from the GCMs output in the range of $50 \mathrm{~km}$. It considers natural forcing (orbital, solar, and volcanic) and anthropogenic forcing (greenhouse gases emission and land use) in describing the feedback mechanisms of climate in terms of orographic rainfall, temperature variation, and other climatic phenomenon in the finer sub-grid scales. The complexity of this model is from the range of the resolutions where it is coarser than the local observation resolutions. In addition, an adequate selection in the boundary condition and climate parameters for the region could also influence the accuracy and the biased parameters (Deser et al., 2012). The RCM used in current study is the HadRM3P which is driven by the Hadley Centre Coupled Model version 3, HadCM3 running for the SRES A1B emission scenario. The simulation was integrated for 141 years from 1960-2100 with every $6 \mathrm{~h}$ update of boundary conditions. However, for the climate change analysis, the baseline climate is calculated from the 30 years period of 1970-1999 (Meng et al., 2013).

Generally, crop production and development are mainly related to climatic variables. Solar radiation, temperature and precipitation values, together with seasonal patterns are the key factors of plant growth over a variety of direct and indirect mechanisms (James et al., 2007). Among all of the variables, air temperature and rainfall distribution influence the vegetative and phenological phases in mango, besides being the most important factors in determining suitability of an area's climate for mango production (Shailendra, 2012). Temperature and rainfall distribution pattern affect flowering, fruit set, fruit growth and fruit development. High value of temperature, rainfall and humidity may force a mango tree to grow continuously without any divergent pause in growth, which will then affect flowering and fruit set. Increase of rainfall intensity during fruit growth and development phase may delay the number of days taken for fruit maturity besides affecting attractive appearance of the fruit (Shailendra, 2012). Different climate at different locations will adversely affected the flowering time, fruiting, yield and quality of fruits (Muhammad et al., 2019). Various climate conditions may describe the fruit quality produced, where increase of drought will delay the maturity of fruit while high temperatures can induce physiological disorder like spongy tissue incidence for Alphonso mango (Sandip et al, 2016).

Growing degree days (GDD) or also known as heat unit is a measurement of the time required for the growth stages development, and can be measured by the average of daily maximum and minimum temperatures compared to a base temperature (Kanzaria et al., 2015; Perry et al., 2001). The base temperature fixed for mango was $17.9^{\circ} \mathrm{C}$, in which heat unit calculations are based on the sum of the temperature units in excess of the base temperature over the growing period above $17.9^{\circ} \mathrm{C}$ (Kanzaria et al., 2015). Fruit growth and maturation, being dependent upon physiological, biochemical and physical processes, will therefore be under the influence of the temperature prevailing during the developmental period (Shinde et al., 2001).

Currently, studies on the impact of different area in Malaysia towards yield and quality of Harumanis is inadequate. Moreover, there are some statements by the locals in Perlis that Harumanis planted outside of Perlis will produce low yield with low quality compared to Harumanis planted in Perlis due to environmental factor. However, there's no scientific prove to support this statement. Thus, the objective of this study is to evaluate the effect of temperature and rainfall distribution pattern towards yield and quality of Harumanis, then further determine future yield production based on future climate projection. 


\section{Method}

\subsection{Experimental Site and Design}

Study was conducted at four different areas which represent two different zones; Zone 1 in the north area of Peninsular Malaysia and Zone 2 in the southern area of Peninsular Malaysia. Figure 1 represents the agro-climatic zone map of Peninsular Malaysia, which can be divided into 3 different zones; Zone 1-area with a clear dry season up to three or four months, Zone 2 - area with a clear dry season between one to two months and Zone 3-area with no dry season. Agro-climatic Zone 1 has been classified as the most suitable area for commercial mango cultivation in Malaysia (Muhammad et al., 2019) as mangoes grow best in climates which have low rainfall and low relative humidity at flowering, fruit setting and harvesting, and that a warm to hot during fruiting (Shailendra, 2012).

Zone 1 includes (i) Chuping, Perlis; (ii) Sintok, Kedah; (iii) Utan Aji, Perlis while Jelebu, Negeri Sembilan located in Zone 2. Three research plots represent Zone 1 whereas only 1 research plot represent Zone 2 as Jelebu is the only area that being planted with Harumanis for the time being. Table 1 indicates the soil properties for each location.

Table 1. Soil properties based on different locations

\begin{tabular}{lllll}
\hline & Chuping & Sintok & Utan Aji & Jelebu \\
\hline $\mathrm{pH}$ & $4.3-4.8$ & $4.6-4.8$ & $4.5-4.7$ & 4.9 \\
$\mathrm{CEC} \mathrm{cmol}(+) / \mathrm{kg}$ & $10-15$ & $<10$ & $15-20$ & $<3$ \\
Clay \% & 40 & 28 & 63 & 35 \\
Silt \% & 30 & 36 & 24 & 9 \\
Sand \% & 25 & 24 & 12 & 42 \\
Coarse Sand \% & 5 & 12 & 1 & 14
\end{tabular}

Note. Soil properties information is based on publication by Malaysia's Department of Agriculture (DOA, 2018).

Treatments comprised of 4 different locations where 25 uniformed plant were selected in every plot using systematic sampling method. Systematic sampling method is a type of probability sampling method where sample from a larger population were selected according to a random starting point but with a fixed, periodic interval. This interval which called as the sampling interval was calculated by dividing the population size by the desired sample size.

$$
\mathrm{k}=\mathrm{N} / \mathrm{n}
$$

Where, $\mathrm{k}$ is the systematic sampling interval, $\mathrm{N}$ is the population size and $\mathrm{n}$ are the desired sample size.

Systematic cultural practices were based on mango management and maintenance manual by MARDI. Portable weather station; Watchdog Weather Station (Series 2000) was installed in every research plot to record daily weather data for every hour beginning from January 2016 to December 2019.

\subsection{Growth Development}

Important date of growth development stages besides cultural practices that applied were recorded. Growth development stages including vegetative phase (begins after pruning), reproductive phase (flower initiation and fruit set) and maturity. Daily and accumulated GDD were calculated together with the total number of calendar days.

$$
\begin{gathered}
\operatorname{GDD}_{\text {(daily) }}=\left(\mathrm{T}_{\max }+\mathrm{T}_{\text {min }}\right) / 2-\mathrm{T}_{\text {base }} \\
\mathrm{GDD}_{\text {(accumulated) }}=\mathrm{GDD}_{\text {day } 1}+\mathrm{GDD}_{\text {day2 }}+\mathrm{GDD}_{\text {day } 3}+\mathrm{GDD}(\text { day(n)) }
\end{gathered}
$$

Where, GDD is the growing degree days, $\mathrm{T}_{\max }$ is the maximum temperature of the day, $\mathrm{T}_{\min }$ is the minimum temperature of the day and $\mathrm{T}_{\text {base }}$ is the base temperature which is $17.9^{\circ} \mathrm{C}$ for mangoes.

\subsection{Yield Production and Fruit Quality}

Fruit sampling were done at every location on different time based on the fruit maturity; data collected as in Table 1 and 2. As for fruit quality analysis, samples were washed using water and soaked in Benomyl fungicide for 10 minutes to prevent post-harvest diseases. Next, samples were dried in ambient temperature before kept in closed box with Calcium Carbide in 3 nights for ripening process before transferred to the laboratory for quality 
analysis. Fruit weight were then measured using analytical balance (AND ER 180A0) whereas total soluble solid (TSS) and total titratable acidity (TTA) were measured using pocket refractometer (Atago PAL-1).

\subsection{Providing Regional Climates for Impacts Studies (PRECIS)}

In Malaysia, PRECIS is currently being used to project SRES A1B emission climate scenario for peninsular Malaysia, Sabah and Sarawak. PRECIS is one of the RCM developed by Met Office Hadley Centre where the model was configured to cover horizontal grid resolution of $0.22^{\circ} \times 0.22^{\circ}$ and 19 levels of hybrid vertical coordinate from ground up to $0.5 \mathrm{hpa}$ (Jones et al., 2004). As for Peninsular and East of Malaysia, the modelling is focused on $95{ }^{\circ} \mathrm{E}$ to $123{ }^{\circ} \mathrm{E}$ and $7.5^{\circ} \mathrm{S}$ to $14{ }^{\circ} \mathrm{N}$ respectively. PRECIS downscales with coarser spatial resolution from the GCMs output in the range of $50 \mathrm{~km}$.

It considers natural forcing (orbital, solar, and volcanic) and anthropogenic forcing (greenhouse gases emission and land use) in describing the feedback mechanisms of climate in terms of orographic rainfall, temperature variation, and other climatic phenomenon in the finer sub-grid scales. The complexity of this model is from the range of the resolutions where it is coarser than the local observation resolutions. In addition, an adequate selection in the boundary condition and climate parameters for the region could also influence the accuracy and the biased parameters (Deser et al., 2012). The RCM used in current study is the HadRM3P which is driven by the Hadley Centre Coupled Model version 3, HadCM3 running for the SRES A1B emission scenario. The simulation was integrated for 141 years from 1960-2100 with every $6 \mathrm{~h}$ update of boundary conditions. However, for the climate change analysis, the baseline climate is calculated from the 30 years period of 1970-1999 (Meng et al., 2013). Future climate has been projected for the periods of $\Delta 2030$ (2020-2040), $\Delta 2040$ (2030-2050) and $\Delta 2050$ (2040-2060).

\subsection{Statistical Analysis}

Data were analyze using one-way analysis of variance (ANOVA) by statistical package in R-Software to detect the effects of different location towards growth development, yield production and fruit quality, whereas means of the treatment were compared using Tukey's test at $\mathrm{p} \leq 0.05$.

\section{Results}

\subsection{Relationship Between Temperature and Rainfall Distribution With Development of Reproductive Stage}

The relationship between temperature and precipitation distribution pattern with Harumanis reproductive stage was evaluated. Changes in temperature and precipitation distribution during flowering, fruit set and maturity for different location and different zone are shown in Figure 2 (Chuping-Zone 1); Figure 3 (Sintok-Zone 1); Figure 4 (Utan Aji-Zone 1) and Figure 5 (Jelebu-Figure 5).

Figure 2 shows that in Chuping (Zone 1), pruning was done in $2^{\text {nd }}$ week of July, followed by induction of flowering in $2^{\text {nd }}$ week of October (12 weeks after pruning). Twelve weeks later, flowers were initiated in the $2^{\text {nd }}$ week of January $\left(\mathrm{T}_{\text {avg }}=26.0^{\circ} \mathrm{C}\right.$, total precipitation $\left.=80.1 \mathrm{~mm}\right)$. Fruit set begins in the $2^{\text {nd }}$ week of March $\left(\mathrm{T}_{\text {avg }}=\right.$ $27.6^{\circ} \mathrm{C}$, total precipitation $\left.=3.6 \mathrm{~mm}\right)$. Fruit starts to mature and ready for harvest in the $2^{\text {nd }}$ week of May $\left(\mathrm{T}_{\text {avg }}=\right.$ $28.5^{\circ} \mathrm{C}$, total precipitation $=47.5 \mathrm{~mm}$ ). 


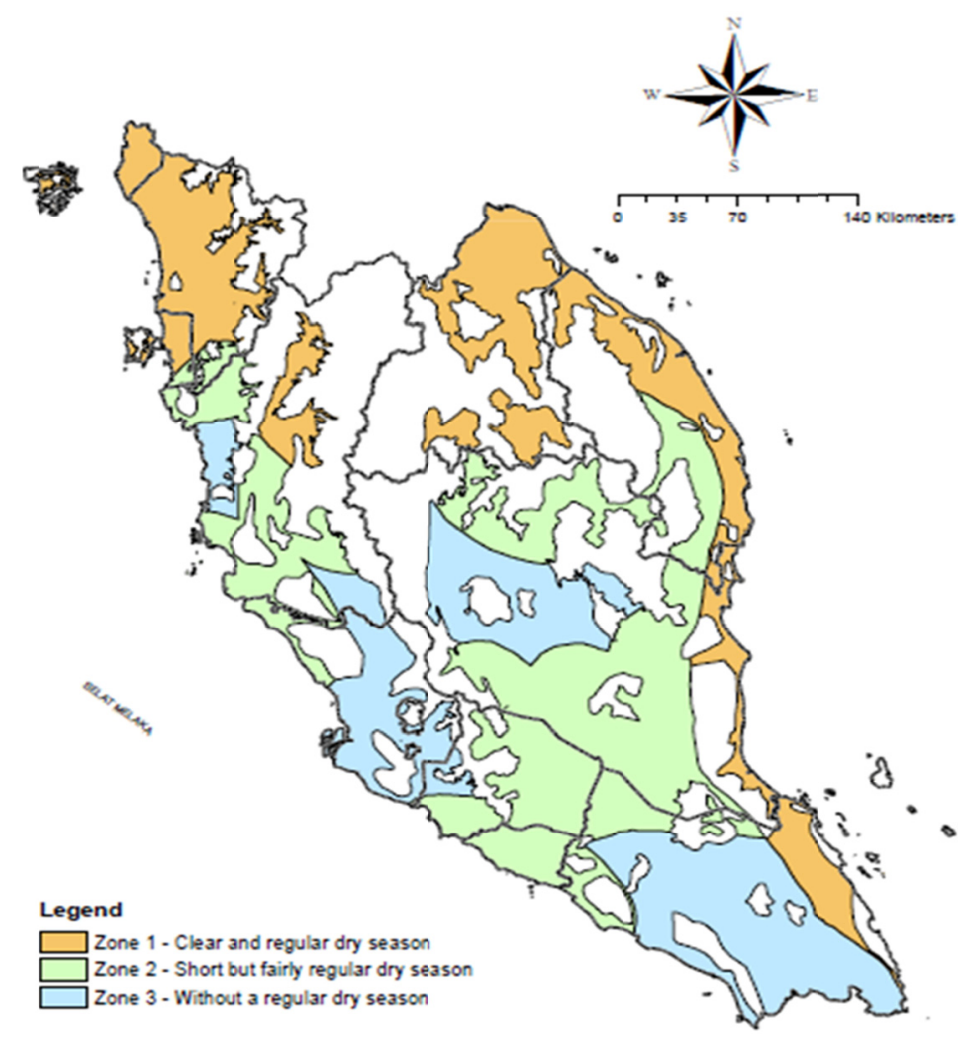

Figure 1. Agro-climatic zone map of Malaysia

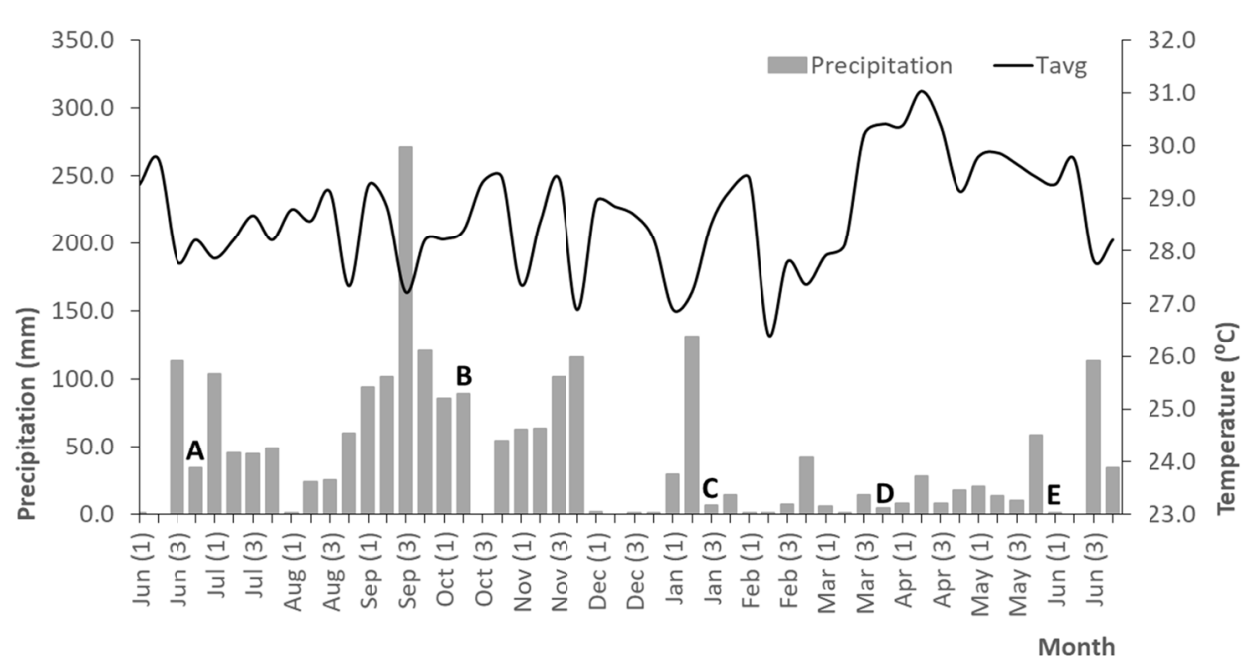

Figure 2. Growth stages, changes of environmental temperature and precipitation trend in Chuping, Perlis; Zone 1 (A: pruning; B: induction; C: flowering; D: fruit set; E: maturity)

Figure 3 shows that in Sintok (Zone 1), pruning was done in $2^{\text {nd }}$ week of August, followed by induction of flowering in $2^{\text {nd }}$ week of November (12 weeks after pruning). Twelve weeks later, flowers were initiated in the $2^{\text {nd }}$ week of February $\left(\mathrm{T}_{\text {avg }}=28.7^{\circ} \mathrm{C}\right.$, total precipitation $\left.=0.8 \mathrm{~mm}\right)$. Fruit set begins in the $2^{\text {nd }}$ week of April $\left(\mathrm{T}_{\text {avg }}\right.$ $=28.9^{\circ} \mathrm{C}$, total precipitation $=20.6 \mathrm{~mm}$ ). Fruit starts to mature and ready for harvest in the $2^{\text {nd }}$ week of June $\left(\mathrm{T}_{\text {avg }}=29.7^{\circ} \mathrm{C}\right.$, total precipitation $\left.=0.0 \mathrm{~mm}\right)$. 


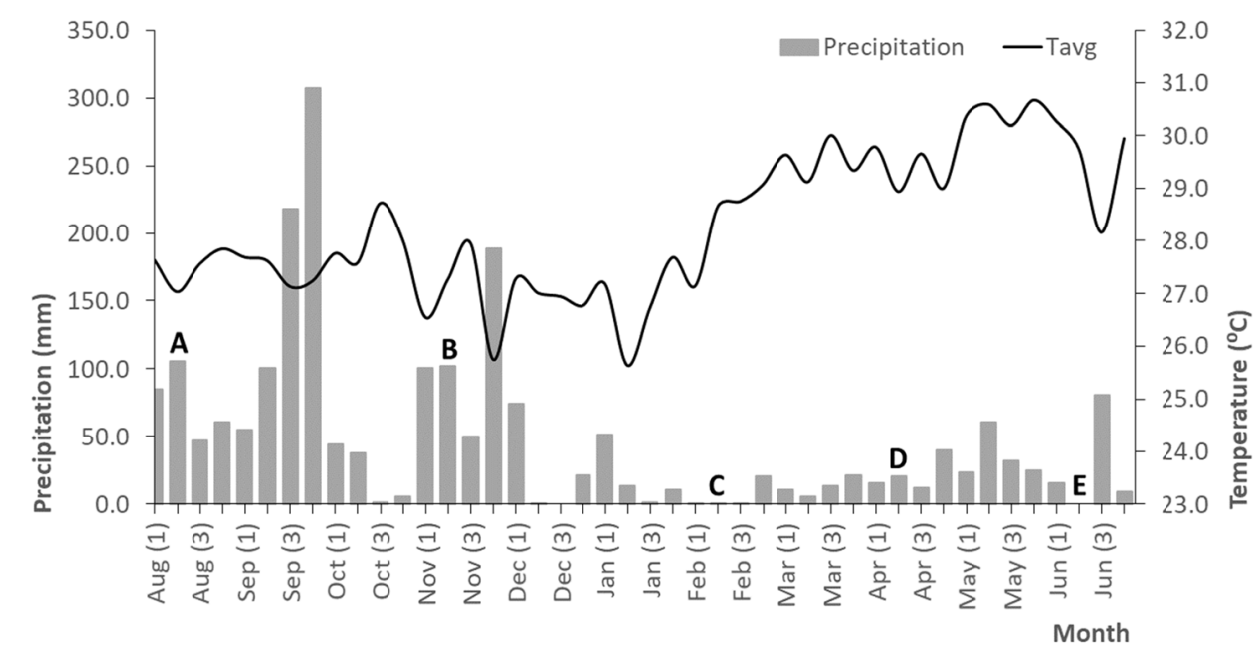

Figure 3. Growth stages, changes of environmental temperature and precipitation trend in Sintok, Kedah; Zone 1 (A: pruning; B: induction; C: flowering; D: fruit set; E: maturity)

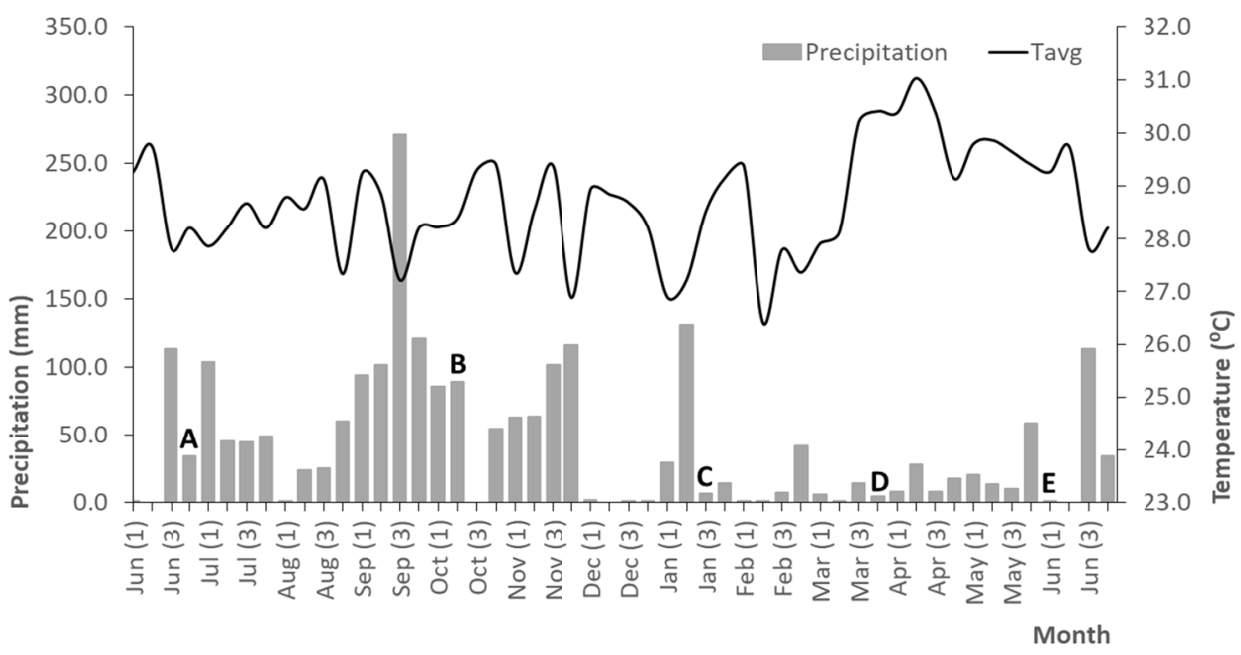

Figure 4. Growth stages, changes of environmental temperature and precipitation trend in Utan Aji, Perlis; Zone 1 (A: pruning; B: induction; C: flowering; D: fruit set; E: maturity)

Figure 4 indicates that in Utan Aji (Zone 1), pruning was done in $4^{\text {th }}$ week of June, followed by induction of flowering in $2^{\text {nd }}$ week of October (14 weeks after pruning). Thirteen weeks later, flowers were initiated in the $3^{\text {rd }}$ week of January $\left(\mathrm{T}_{\text {avg }}=28.5^{\circ} \mathrm{C}\right.$, total precipitation $\left.=6.4 \mathrm{~mm}\right)$. Fruit set begins in the $4^{\text {th }}$ week of March $\left(\mathrm{T}_{\text {avg }}=\right.$ $30.4^{\circ} \mathrm{C}$, total precipitation $\left.=4.4 \mathrm{~mm}\right)$. Fruit starts to mature and ready for harvest in the $1^{\text {st }}$ week of June $\left(\mathrm{T}_{\text {avg }}=\right.$ $29.3^{\circ} \mathrm{C}$, total precipitation $=0.2 \mathrm{~mm}$ ).

Figure 5 shows that in Jelebu (Zone 2), pruning was done in $2^{\text {nd }}$ week of August, followed by induction of flowering in $2^{\text {nd }}$ week of November ( 12 weeks after pruning). Thirteen weeks later, flowers were initiated in the $3^{\text {rd }}$ week of February $\left(\mathrm{T}_{\text {avg }}=26.3{ }^{\circ} \mathrm{C}\right.$, total precipitation $\left.=12.4 \mathrm{~mm}\right)$. Fruit set begins in the $2^{\text {nd }}$ week of April $\left(\mathrm{T}_{\text {avg }}=26.8^{\circ} \mathrm{C}\right.$, total precipitation $\left.=16.2 \mathrm{~mm}\right)$. Fruit starts to mature and ready for harvest in the $2^{\text {nd }}$ week of June $\left(\mathrm{T}_{\text {avg }}=26.7^{\circ} \mathrm{C}\right.$, total precipitation $\left.=12.3 \mathrm{~mm}\right)$. 